\title{
Has COVID-19 Started to Reveal the Jobs of the Future?
}

\author{
Devaki Chandra \\ Tutor for Distance Learning
}

\begin{abstract}
Are we starting to see the jobs of the future through the COVID-19 pandemic? This paper argues that in a few industries such as agriculture, healthcare, education, and mental health, we are starting to see jobs that we didn't fully imagine a few years ago. Online appointments can increase attendance of reluctant mental health patients, such as military veterans. Conferences may have a remote option so that more people could attend, particularly from other countries. Agricultural workers could access on-site healthcare as needed, or the remaining workers, after automation, could get immediate medical help in the case of an injury. Providing protective equipment, its manufacture and distribution, could be part of a new higher standard of hygiene in providing oral care. While all the changes will not be permanent, the pandemic's duration is giving us an idea of how the workplace will change. The pandemic has increased the role telecommunications and information technology play in an economy that had already come to rely on both to fuel a workstation.
\end{abstract}

Keywords: technology, regulation, equity

\section{INTRODUCTION}

Are we starting to see the jobs of the future through the COVID-19 pandemic? In 2020 remote working and remote learning became a necessity to empty common spaces because of the pandemic. It enhanced remote communication and made live interaction, such as in restaurants or theaters, harder to continue. This paper argues that in the United States we are seeing a development of the jobs that we didn't imagine a few years ago. Remote working and learning will certainly be used in the future, but how much remains to be seen.

This paper looks at which industries have been affected. The pandemic has required more protective equipment and additional space for patients to be examined in healthcare. It also has seen the rise of videoconferencing for appointments. Equipment has been bought and staff hired to support needs until an unknown time in 2021. Education has been changed with distance learning and pods, but the change has not always been welcome because it has exposed inequity of access. Remote learning will continue where it was successful. The pandemic is increasing the role telecommunications and information technology play in an economy that had already come to rely on both to fuel a workstation.

Looking at the future of the workplace requires that the pandemic is brought under control. Remote working and distance learning is currently part of the workplace, but it is unclear how long it will last. It depends on how long that environment is adversely affected by the pandemic. We will look at the sectors of agriculture, education, healthcare, and mental health. 


\section{LITERATURE REVIEW OF COVID-19 AND HOW IT WILL AFFECT THE WORKPLACE}

Controlling the pandemic is a priority for every country, if not the highest priority. In the United States, it has become the top priority for the government since the economy cannot fully operate without controlling the disease. For this year, COVID-19 dominates the workplace. The new administration passed the American Rescue Act of 2021 to support recovery from the pandemic physically and economically. Now it will be a question of how funds can support workplaces to be sustainable. This is the workplace of the present until the virus is no longer infecting and killing people. This calendar year, 2021, will be affected; but it is unclear if next year will be to the same extent.

The aim for state governments and federal governments is to work together to supply the vaccination that is now available against the disease. This means that the states are not competing with each other for supplies or against a federal agency such as FEMA for Personal Protective Equipment (PPE). This requires a good supply chain for the vaccination with ample cold storage, good information on who can obtain it and where; and finally, good education on the safety of the vaccine such as any side effects to expect. It is also valuable to know risks that it might create for some individuals, such as those with asthma or other preexisting conditions that can result in the rare instance of blood clots.

None of this is easy to do and creating jobs for ensuring a smooth distribution could be employment opportunities for some. Financial support for healthcare workers from the American Rescue Act of 2021 would provide compensation for those already trained and possibly to train more to administer the vaccination. Workplaces, whether department stores or schools have invested in equipment to make it possible to continue activity with COVID precautions, such as plexiglass shields, software for editing and sharing capability with assignments, and graphing capabilities for online instruction. At this time, the COVID-19 case rate is still high but declining. The United States and its allies have been able to produce a vaccine and slow down the spread, but not yet defeat the virus.

A literature is emerging on this topic from the last year. One paper is Chernoff and Warman (2020) on automation, technology implemented to relieve health risks of transmission of the virus. Jobs such as secretaries and cashiers have been identified as both high transmission and high automation potential. Personal care aide was also included, for housework and lifting residents. Since the disabled and the elderly often prefer the human touch in such work, this is surprising. It is a question of whether automation wouldn't leave that population more socially isolated ${ }^{1}$, a significant factor to using automation. Human companionship can make a big difference to this population. Finally, another paper found a statistical significance in lagged unemployment, not current unemployment ${ }^{2}$. That accounts for adjustment to the changing circumstances.

Jobs could be created in addressing where the relief effort has been deficient. OSHA (Occupational Safety and Health Agency) will have to hold more companies accountable if the spread of the virus is to be contained. This is true in the agricultural sector that is in the rural areas and part of our food supply. The virus spread to the rural areas of the U.S. after starting in the urban areas. Containing the virus is that much more difficult with this reduction in healthcare access. The distance between hospitals and the older population have made the outbreak in these areas more acute. Meatpacking plants were hit hard in April and May as cases soared. OSHA had not conducted inspections at 40 percent of meatpacking plants ${ }^{3}$. Of roughly 500,000 workers in the meat-processing industry, 16,000 tested positive. Deaths were unreported at companies such as Seaboard Food ${ }^{4}$ and deaths were not reported at plants in the states such as Iowa. Fines, however, were made in states such as Texas, but not considered sufficient by worker groups. Undocumented workers can make up to 14 percent of the meatpacking workers ${ }^{5}$. It's possible that these workers don't have access to many community health services. It might have been because a sick employee could be easily replaced, from a pool of undocumented workers.

\section{MORE AUTOMATION IN THE FUTURE?}

The American Rescue Act of 2021 offers a number of ways to help ensure worker safety ${ }^{6}$ : provide paid leave for workers in quarantine and isolation; funds to ensure testing, and vaccination; provide conditions 
for workers to take a vaccination; require that action be taken within 150 days of the bill's enactment. This would be in 2021, $\$ 4$ billion allocated in total including loans to small and medium-size distributors or processors. Whether there is a penalty for companies not to report outbreaks and deaths depends on how well the regulations are enforced; enforcing these regulations would strengthen the employment in this sector. The relief effort would cover resources to make the workplace safer so that the companies stay solvent; the time requirement would hasten the services being received by the workers and workers would benefit.

An alternative is increasing automation in meatpacking factories that reduces human risk ${ }^{7}$. That has already happened in warehouses and a way companies could avoid health regulation. Despite agriculture, food, and related services occupying 10.9 percent of the work force, for example, Tyson Foods has invested in automation in the last three years. ${ }^{8}$ Five hundred million dollars was invested in automation for tasks like irrigation and harvesting that has been employment for recent immigrants, possibly undocumented. They said lasers could chop vegetables, another job that unskilled workers have filled in the past. It would hurt the employment prospects of those workers as fewer workers are needed. Injuries may grow among the remaining higher-skilled workers if the machines malfunction in some way. We can hope that the workplace of the future will have tighter regulations to avert the spread of this kind of deadly virus or machine-oriented injury in the future, but it will depend on whether management enforces those regulations. It might be cheaper to use robots to do the work of the employees eventually. With the pandemic, companies have been forced to acknowledge the regulations.

\section{EDUCATION}

A good internet connection is vital for good distance learning. There is asynchronous learning and synchronous learning. ${ }^{9}$ In asynchronous learning, the students go at their own pace. Synchronous learning, where a teacher is present, requires that a pupil can see and hear the teacher. To be part of a discussion, the pupil has to be able to hear the other members of the class. Internet links have to be consistent or the pupils can be shut out of classes if they don't have the right links. Handing in work can require software that can photograph work done by hand for young children. The logistics of distance learning seem to have been the hardest on young children in the K-12 system. They are learning their letters and arithmetic while the reception of communication may not be adequate. There might be noise in the reception. For young children it is their first experience outside of the home. The absence of social interaction, particularly with their peers, is harder for them to absorb. The younger the child, the harder it is to learn the material in this format. Tutors have been helping young children stay engaged and for social interaction, pods of children have been formed. Tutoring certainly is a job for the present and will last as long as school remains closed. It exacerbates access inequities, however, as long as some children don't have access to the internet as others do.

High school students can manage better, as they are often more familiar with the technology. This is assuming they are engaging in school at all, which is not a foregone conclusion with teenagers losing hope about planning for the future or rebelling in general. Emergency room visits for mental health problems have been up 30 percent for teens over the pandemic ${ }^{10}$. Between the ills of isolation and if social media makes them feel bad about themselves, they are more affected by remote learning in a different way than the young pupils. They often know how to use the technology better but they may disengage out of not seeing the point, i.e. depression of some kind. In one large school district that had been remote since March, high-school students with failing grades in two or more classes made up 11 percent of total by December $2020 .^{11}$

Distance learning will be more normalized for continuous learners, who are usually adults. MOOCs (Massive Open Online Courses) will benefit increased online learning for students who are more used to working at their own pace, asynchronous learning. It's possible that some college students will continue online, but since living away from home has been a big part of the college experience, the majority would probably want to return to campus. In rural areas, the Federal Communications Commission in 2018 cited mobile connectivity at a high rate of near $100 \%$. For fixed services ${ }^{12}$, such as a laptop, the penetration rate 
is lower. Nationally, it has been 77 percent and in Arizona, it was 46.8 percent $^{13}$. This affects how well online classes can be conducted, particularly lab classes in high school or classes for young children. Mobile device penetration is widespread and so the better the quality of service on the mobile devices, the better the service delivery will be.

\section{HEALTHCARE}

Healthcare as a sector is different from education. Many services have to be in person in order for them to be delivered. Protective equipment is worn for in-person appointments, such as dentistry or orthodonture. That protective equipment will stay on until the virus is under control. It's possible that the protective equipment will be part of a higher standard of hygiene in medicine in oral medicine for the foreseeable future.

In 2019, roughly 50 million people lived in rural areas of the country. It is not a large share of the population (about one-sixth), but that population is involved with agriculture that is vital for the rest of the country. There are 56 counties in rural areas where poultry and meatpacking industry was twenty percent of employment that year. While COVID-19 was slow to hit these areas last winter, it hit hard through May and then again in July. A feature of rural life is the distances to hospitals and an older population. It also has more people who lack health insurance ${ }^{14}$, estimated as large as 20 percent by the USDA. Between 2016 and 2017, 4 percent of the counties in the United States (116) lacked a medical clinic or a hospital. Only 60 percent of counties with hospitals have an ICU ( Intensive Care Units), that have been critical for COVID19 patients. Twenty-three percent of those residents are recorded as having underlying health problems, ages 20 to 84. It includes young adults as well as the elderly. These factors contributed to the outbreak of COVID-19 and subsequent deaths greater than in the metro areas.

\section{MENTAL HEALTH CARE, AS OPPOSED TO PHYSICAL HEALTH CARE}

For appointments like therapy, Telehealth may become more common. A primary advantage is reaching more people, particularly in rural areas if their internet is strong enough. The American Rescue Act has allocated funds for services such as mental and behavioral health $(\$ 110 \mathrm{M})$, community behavioral health $(\$ 420 \mathrm{M})$, and youth suicide prevention $(\$ 20 \mathrm{M}) .^{15}$

Some version of tele psychology has been around since 1960 and it has been effective with patients of Post-Traumatic Stress Syndrome, such as veterans. Retention rates have been higher with such populations because there is less effort to keep receiving it and one population where both in-person and tele psychology have been roughly equally effective ${ }^{16}$. In recent decades, geographically isolated HIV-positive adults have found it reduced depression for about one-third of those who tried it. Uscher-Pines et al. (2020) found that unplanned visits for behavioral health and chronic illness contributed to year-over-year growth in Telehealth visits. If the patients prefer it, it could be a sign of service to come.

The intimacy of conversation can largely be duplicated in that setting, in contrast to performing a physical examination. It may also take away stigma from seeking mental health treatment. As COVID-19 restrictions lift, whenever that happens, some clients or patients will stay with Telehealth if it suits their lifestyle.

\section{VIDEO CONFERENCING}

Video conferencing will help in rural areas if broadband is sufficiently good. It will be possible for as close to in-person meetings for business negotiations or a sales presentation. The Federal Communications Commission in 2018 cited a $99.4 \%$ penetration rate for Mobile devices in rural areas, an encouraging statistic $^{17}$. For meetings, as opposed to classes, this would enhance communication and care.

The meeting space has changed to online meeting over the last year. The positive effect is that more people can attend meetings virtually than might have attended in person. Globally, this can make all the 
difference to conferences where students might not have been able to attend before. Political fund-raisers have also included more people, who might never have come in person. ${ }^{18}$

\section{CONCLUDING REMARKS}

Online learning will continue for those where it has been successful. It's unclear, however, whether that is for the majority of the student population taking classes and the educational sector will probably use remote learning as a back-up should in-person teaching be restricted again. COVID-19 has made the workplace less centralized and for meetings, online gatherings will probably continue, across manufacturing to service industries. Telemedicine, however, will probably not continue, since it involves a physical examination. The exception is that of mental health, where talking and general communication is a big part of the treatment. Masks will be part of our attire for at least this year, however. In agriculture, automation may accelerate to avoid enforced regulation for safety of the workers, but it's possible that regulations will be enforced to keep the community safe. In conclusion, COVID-19 has started to show us the jobs of the future. Right now, these jobs are to address COVID-19, particularly in education. But eventually, the jobs in these sectors could be enhanced to bridge divides, such as outreach and organizing in community development towards a more equitable society.

\section{ENDNOTES}

1. Aaron Smith and Monica Anderson. “ Automation in Everyday Life.” Pew Research Center, October 4, 2017. p.46, Sixty-four percent of respondents to a Pew survey say the elderly would be more isolated.

2. Diane Charlton and Marcelo Castillo, "Potential Impacts of a Pandemic on the U.S. Farm Labor Market." Applied Economic Perspectives and Policy, wileyonlinelibrary.wiley.com, Volume 43, March 2021.

3. Kyle Bagenstose, Sky Chadde, and Rachel Axon. "COVID-19 Deaths Go Un-investigated as OSHA Takes a Hands-off Approach to Meatpacking Plants" usatoday.com, January 11, 2021.

4. Bagenstose et al. p. 6.

5. Stephen Groves and Sophia Taren, "U.S. meatpacking industry relies on immigrant workers. But a labor shortage looms". Los Angeles Times, May 26, 2020.

6. H.R. 1319 Subtitle A-Agriculture, Section 1002.

7. Jason Del Rey." How Robots are Transforming Amazon Warehouse Jobs-for Better or for Worse." vox.com, December 11, 2019.

8. Marcus Casey and Ember Smith, “Automation from Farm to Table”. https://brookings.edu/ Up Front, November 23, 2020.

9. Maria Ocando Finol, “Asynchronous vs. Synchronous Learning: A Quick Overview”, brynmawr.edu, March 26, 2020.

10. from April to October 2020 over the same period in 2019. Beth Ann Mayer, "Remote Learning Could Be Hurting Teenagers' Mental Health-Here's How to Spot Warning Signs in Your Child", parents.com, February 4, 2021.

11. Susan Dominus, “Where the Schools Stayed Open.” New York Times Magazine, February 14, 2021, p.35. The school district was in Fairfax County, Virginia.

12. fixed terrestrial broadband service is defined by an upload and download capability. So a desktop or laptop computer would fall in that category. A mobile device would probably be slower.

13. Appendix 2, FCC 20-50, Federal Communications Commission, 2018, June 8, 2020.

14. John Cromartie. Et al. "Rural America at a Glance." USDA December 2020,p.3.

15. H.R. 1319,Subtitle H-Mental Health and Substance Abuse Disorder, Sections 2706 (\$30 M), 2707 (\$50M), $2708(\$ 10 \mathrm{M}), 2710(\$ 20 \mathrm{M}), 2711(\$ 100 \mathrm{M})$, and $2713(\$ 420 \mathrm{M})$.

16. Zara Greenbaum, p.2 Article cited is "Systematic review of lessons learned from delivering tele-therapy to veterans with post-traumatic stress disorder"

David Turgoose, Rachel Ashwick, Dominic Murphy Journal of Telemedicine and Telecare, 2017, PMID: 28958211 DOI: $10.1177 / 1357633 X 17730443$

17. Appendix 1,FCC 20-50, Federal Communications Commission, 2018, June 8, 2020.

18. Fund-raisers for the Georgia Senate election by Stacey Abrams and an International Women's Day event are two examples. 


\section{REFERENCES}

Abdul, G. (2021, February 12). Months After Losing a Job, Taking Pride in Helping Out. The New York Times, 1, B1, B5.

American Rescue Act 2021 (H.R. 1319).

Bagenstose, K., Chadde, S., \& Axon, R. (2021, January 11). COVID-19 Deaths Go Un-investigated as OSHA Takes a Handsoff Approach to Meatpacking Plants. Retrieved from usatoday.com

Bureau of Labor Statistics, U.S. (n.d.). Agriculture and Related Industries. Retrieved from https://fred.stlouisfed.org

Carey, B. (2021, March 16). For Some Teens, a Year of Anguish. Science Times. The New York Times.

Casey, M., \& Smith, E. (2020, November 23). Automation from Farm to Table. Up Front. Retrieved from https://brookings.edu/

Charlton, D., \& Castillo, M. (2021, March). Potential Impacts of a Pandemic on the U.S. Farm Labor Market. Applied Economic Perspectives and Policy, 43. Retrieved from wileyonlinelibrary.wiley.com

Chernoff, A.W., \& Warman, C. (2020, November). COVID-19 and Implication for Automation. Working Paper 27249, National Bureau of Economic Research. http://www.nber.org/papers/w27249

Cromartie, J., Dobis, E.A., Krumel, T.P., Jr., McGranahan, D., \& Pender, J. (2020, December). Rural America at a Glance. U.S. Department of Agriculture (USDA).

Del Rey, J. (2019, December 11). How Robots are Transforming Amazon Warehouse Jobs-for Better or for Worse. Retrieved from vox.com

Domininus, S. (2021, February 14). Where The Schools Stayed Open. New York Times Magazine, pp. $32-41$.

Domininus, S. (2021, May 16). I Feel Like I'm Just Drowning. New York Times Magazine, 20-35, 47-50, 53.

Dornauer, M.E., \& Bryce, R. (2020, October 28). Too Many Rural Americans Are Living in the Digital Dark: The Problem Demands a New Deal Solution. Health Affairs.

FCC 20-50, Federal Communications Commission. (2018). June 8, 2020, Appendices 1, 2.

Gerdeman, D. (2021, March 8). COVID Killed the Traditional Workplace. What Should We Do Now? Harvard Business Review. Working Knowledge. Retrieved from hbswk.hbs.edu

Greenbaum, Z. (2020). How Well is Telepsychology Working? American Psychological Society, 5 1(5).

Groves, S., \& Taren, S. (2020, May 26). U.S. meatpacking industry relies on immigrant workers. But a labor shortage looms. Los Angeles Times.

Hernandez, D., \& Hinshaw, D. (2021, February 7). As Covid-19 Vaccines Raise Hope, Cold Reality Dawns that Illness is Likely Here to Stay. The Wall Street Journal.

Hoffman, J. (2021, February 16). To Get Lives Back, Some Teens Volunteer for Trials. The New York Times, $A 4$.

Huber, M. (2020, September 10). OSHA Fines Smithfield Foods for failing to protect employees from the coronavirus. 'Retrieved from www.argusleader.com

Hussein, F. (2020, May 5). Smithfield Wins Dismissal of Meat Workers Virus Safety Suit. Retrieved from www.bloomberglaw.com

Mayer, B.A. (2021, February 4). Remote Learning Could Be Hurting Teenagers' Mental Health-Here's How to Spot Warning Signs in Your Child. Retrieved from parents.com

Ocando Finol, M. (2020, March 26). Asynchronous vs. Synchronous Learning: A Quick Overview. Retrieved from brynmawr.edu

Schindelheim, R. (n.d). Retrieved from WorkingNation.com

Seabrook, J. (2021, January 25). Has the Pandemic Transformed the Office Forever? The New Yorker. Retrieved from newyorker.com

Smith, A., \& Anderson, M. (2017, October 4). Automation in Everyday Life. Pew Research Center.

Stringer, H. (2020, October 13). Zoom school's mental health toll on kids. American Psychological Association, online-learning, mental health. Retrieved from www.apa.org

118 Journal of Applied Business and Economics Vol. 23(4) 2021 
Turgoose, D., Ashwick, R., \& Murphy, D. (2017). Systematic review of lessons learned from delivering tele-therapy to veterans with post-traumatic stress disorder. Journal of Telemedicine and Telecare. PMID: 28958211 DOI: 10.1177/1357633X17730443

Uscher-Pines, L., Thompson, J., Taylor, P., Dean, K., Yuan, T., Tong, I., \& Mehrotra, A. (2020). Where Virtual Care Was Already a Reality: Experiences of a Nationwide Telehealth Service Provider During the COVID-19 Pandemic. Journal of Medical Internet Research, 22(12). 